\title{
Relevance of Health Economics in Breast Cancer Treatment: Integration of Economics in the Management of Breast Cancer at the Clinic Level
}

\author{
Volker R. Jacobs Gerhard Bogner Christiane E. Schausberger \\ Roland Reitsamer Thorsten Fischer \\ Frauenklinik (OB/GYN) of Salzburger Landeskrankenanstalten (SALK) and Paracelsus Medical University (PMU), Salzburg, Austria
}

\section{Keywords}

Breast cancer - Costs of treatment - Limited resources .

Microeconomic solutions $\cdot$ Health economics

\section{Summary}

Since the introduction of the diagnosis-related groups (DRG) system with cost-related and entity-specific flat-rate reimbursements for all in-patients in 2004 in Germany, economics have become an important focus in medical care, including breast centers. Since then, physicians and hospitals have had to gradually take on more and more financial responsibilities for their medical care to avoid losses for their institutions. Due to financial limitations of resources, most medical services have to be adjusted to correlating revenues, which results in the development of a variety of active measures to understand, steer, and optimize costs, resources and related processes for breast cancer treatment. In this review, the challenging task to implement microeconomic management at the clinic level for breast cancer treatment is analyzed from breast cancer-specific publications. The newly developed economic management perspective is identified for different stakeholders in the healthcare system, and successful microeconomic projects and future aspects are described.

\section{Introduction}

As a result of economic globalization, there is a continuing and accelerating trend treating all aspects of live from an economic perspective, including the economization of medicine.

\begin{abstract}
Schlüsselwörter
Brustkrebs · Behandlungskosten - Beschränkte Ressourcen · Mikroökonomische Lösungen · Gesundheitsökonomie

\section{Zusammenfassung}

Seit Einführung des DRG (diagnosis-related groups)Systems mit kostenbezogenen und krankheitsspezifischen Pauschalvergütungen für stationäre Patienten im Jahr 2004 in Deutschland ist Wirtschaftlichkeit zu einem wichtigen Schwerpunkt in der medizinischen Versorgung auch von Brustzentren geworden. Seitdem mussten Ärzte wie Krankenhäuser sukzessiv und zusätzlich die volle finanzielle Verantwortung für ihre medizinische Versorgung übernehmen, um Verluste für ihre Institutionen zu vermeiden. Aufgrund von finanziell begrenzten Ressourcen muss jede medizinische Dienstleistung im Durchschnitt an die korrelierende Einnahme angepasst werden, was zur Entwicklung einer Vielzahl aktiver Maßnahmen zum Verständnis, zur Steuerung und zur Kosten- und Ressourcenoptimierung sowie dazugehöriger Prozesse geführt hat. In dieser Übersicht soll die Herausforderung der Einführung von Wirtschaftlichkeit und mikroökonomischen Lösungen im Klinikalltag auf der Basis brustkrebsspezifischer Publikationen analysiert werden. Die neuentwickelte ökonomische Managementperspektive wird aus der Sicht verschiedener Stakeholder im Gesundheitssystem identifiziert und erfolgreiche wirtschaftliche Projekte sowie zukünftige Entwicklungen beschrieben.
\end{abstract}

Depending on the individual health-political history and value of healthcare for each society, different countries have over the years defined their country-specific individual solutions to control rise of costs in healthcare. Irrespective of whether this development is supported or not, it cannot be ignored by any

\section{KARGER \\ Fax +497614520714 \\ Information@Karger.com}

www.karger.com (c) 2013 S. Karger GmbH, Freiburg

$1661-3791 / 13 / 0081-0007 \$ 38.00 / 0$

Accessible online at:

www.karger.com/brc
PD Dr. med. Volker R. Jacobs, MBA

Frauenklinik (OB/GYN)

Salzburger Landeskrankenanstalten (SALK) and Paracelsus Medical University (PMU)

Müllner Hauptstr. 48, 5020 Salzburg, Austria

volkerjacobs@hotmail.com 
profession in medicine since it affects and complicates daily clinical practice in numerous ways. At the present time medicine and healthcare have to be considered professional services, and their resource use is competing with the consumption of consumer goods such as new smartphones, cars, and foreign holidays. Governments are providing the political and economic rules for any healthcare system and are balancing the interests of citizens, industry, and all other stakeholders by regulating healthcare and its related costs to limit the almost unpreventable cost increase.

As a consequence medicine cannot exclusively be practiced according to professional ethics with the target of unlimited optimal quality of care solely in the interest of patients and independent of the resources available. Today healthcare is financially embedded into the complex overall concept of each society, and ranges widely in resource consumption which is reflected by a gross national product (GNP) spending of $8-16 \%$ by industrial nations. Different amounts of spending result naturally in different therapy options. As a consequence of the economization of medicine, optimal care and medical ethics without resource limitations are a utopic concept since all spending options for any healthcare system correlate with health and social insurance fees and/or tax revenues. Therefore any society has to decide how much it is willing to pay for medical care. Germany for decades has repeatedly been using healthcare reforms every couple of years to limit the continuing cost increase and inevitable medical service expansion. The introduction of diagnosis-related groups (DRGs) in Germany finally took place in 2004, with a highly sophisticated cost-related and entity-specific flat-rate reimbursement for all in-patient entities, and was a landmark decision changing the performance of medicine ever since. Independent of the quality and level of medical care, all institutions are being paid identical within a small window of just a few percent. This decision transferred the economic responsibility of in-patient healthcare costs from health insurances and government institutions onto the side of hospital-employed physicians and their institutions. As a result length of stay in hospitals was remarkably reduced, and costs for diagnostics and therapy had to be actively adjusted to the correlating revenues for the first time. The new economic rules went even further because to cover treatment costs for unavoidable cost outliers the average spending target had to be set even below the average flat-rate reimbursement. As a result the overall medical concept had to be adjusted from providing unconditional best care to best financially affordable care within the cost frame given by all revenues generated. This naturally leads to limitations including prioritizing or even rationing of expensive resources. Although this fact is constantly denied by all politicians in power, it has become daily clinical routine and a problem to be solved by medical professionals. Although a professional challenge and change, and despite unethical concerns by physicians, these basic economic rules newly implemented by Germany society were accepted over time and are successively converted into daily medical practice. After almost a decade with DRG payment, the issue that this flat-rate reimbursement system includes neither a profit margin to compensate potential losses nor additional payments for costly structural quality measures like for certified breast centers remains unsolved. The system also does not cover costly maximum care institutions like university clinics or includes a payment according to quality outcome. As a consequence of this entire development, the management of economic aspects of breast cancer treatment at the clinic level has gained increasing attention. On this background, this review analyses the development of economic aspects and their implementation into the medical management of breast cancer treatment since the introduction of DRGs in Germany, identifies new management tasks, and analyses how problems and their potential solutions at the microeconomic level can be addressed.

\section{Methods}

A Medline search was performed on Dec $11^{\text {th }} 2012$ for the 2 main keywords 'breast cancer' and 'Germany' combined individually with the following 11 keywords: 'DRG/-s', 'cost/-s', 'revenue/-s', 'economics', 'cost-coverage', 'financial loss', 'reimbursement', and 'cost-effectiveness'. To identify all publications published in context with the current DRG system, the search was performed within the time frame of Jan $1^{\text {st }} 2004$ to now. All references found were further analyzed regarding content, context, and appropriateness with regard to economic management of breast cancer. Additionally related references from unsystematic internet searches and websites were included whenever appropriate. Derived from publications, other sources and professional experience, a detailed analysis of the economic management perspective of different stakeholder was performed with special focus on successful microeconomic examples for improved cost-coverage from the care providers' perspective at the clinic level in breast centers.

\section{Results}

The Medline search for 'breast cancer' and 'Germany' with the individual key word searches resulted in $+\cos t n=73$, + costs $\mathrm{n}=57,+$ DRG $\mathrm{n}=7,+$ DRGs $\mathrm{n}=6$, +revenue $\mathrm{n}=2$, + revenues $\mathrm{n}=2$, +economics $\mathrm{n}=62$, +cost-effectiveness $\mathrm{n}=23$, +reimbursement $\mathrm{n}=9$, +financial loss $\mathrm{n}=4$, and + costcoverage $n=3$. Combined, the search resulted in $n=99$ individual publications. Based on the abstract information, the content was evaluated regarding economic aspects as core topic, and $n=47 / 99$ (47.5\%) publications were eliminated from further evaluation accordingly. 2 references were eliminated because of redundancy. The analysis of economic topics for the remaining $\mathrm{n}=50$ confirmed a main focus on the core topics cost-effectiveness $\mathrm{n}=18$, divided into pharmaceuticals $\mathrm{n}=8$, diagnostics $\mathrm{n}=7$, therapy $\mathrm{n}=2$ and implants $\mathrm{n}=1$, followed by cost-related process optimization $n=7$, cost-coverage $\mathrm{n}=5$, prevention/screening $\mathrm{n}=4$ and cost-utility analysis, certified breast centers, cost of illness and editorials/politics 
by $\mathrm{n}=3$ each, DRG analysis $\mathrm{n}=2$ and costs/prices and methods $\mathrm{n}=1$ each. Economic aspects were distributed unevenly over the years with the majority being published more recently. Although many papers were published about economic aspects, only a few of these publications identified deal specifically with micro-/economic management of breast cancer treatment.

\section{Discussion}

The analysis of references regarding economic aspects related to breast cancer in Germany since 2004 confirms that economic aspects have increasingly found their way into medical publications. While in the past all cost aspects were often covered with an unsubstantiated typical single sentence '...was found to be cost effective...', recently a variety of topics dealing with economics and breast cancer management and reimbursement have been published. This confirms that the introduction of the DRG system has led to the incorporation of DRG-implicated economic aspects and concepts into daily medical care. However many cost-effectiveness analyses are not helpful from the care providers' perspective because they often take an overall approach from a society's perspective [1], not explicitly addressing that cost-effective therapy might not be cost-covering for the clinic and care provider at all. In summary, the references found represent only partially the actual effect and influence of economic aspects in hospitals on breast cancer treatment within the last decade.

\section{Cost of Breast Cancer Treatment}

The number of all in-patient DRG cases within DRG category MDC09 including breast, skin and subcutaneous tissue increased from $\mathrm{n}=479,674$ in 2004 to $\mathrm{n}=529,115$ in 2008 $(+10.3 \%)$ and had a relative proportion of $4.22 \%$ of all in-patient DRGs in Germany in 2008 [2].

The cost of breast cancer treatment can be divided into direct and indirect costs. Direct costs of breast cancer treatment such as for diagnostics like imaging or for treatment like operations or chemotherapy are relatively easy to calculate either from cost calculations by the care provider resulting in the DRG cost matrix done by the Institut für das Entgeltsystem im Krankenhaus (InEK) every year or the fixed amount of DRG reimbursement of the payer for each DRG which can be found in InEK's DRG report browser [3]. However both calculations are not complete because underestimation is likely, and costs and their correlating reimbursement can in each case vary quite dramatically. Furthermore, there are out-of-pocket payments by patients divided into known and unknown.

Indirect costs of breast cancer treatment are complex and difficult to define because numerous aspects have to be included such as decreased quality of life, lost years of life, but also unpaid work as mother and/or household caretaker, taxpayer, social insurance payer, lost work force, costs for private care and caretakers, disease-related costs not covered by insurances, alternative medication, complementary and alternative medicine (CAM), wigs for alopecia, transportation costs, cosmetic devices, etc. This may be the reason why the exact cost of breast cancer treatment in Germany per year is still unknown; the methods and definitions of which data to include and how to collect standardized and reliable data have not been exactly defined so far. Cost-of-illness analyses based on models or estimates have been performed for cancer and breast cancer in the U.S. [4-6], also in the metastases setting $[7,8]$ and even considering often neglected indirect costs like missing labor force re-entry in Canada [9]. Cost calculations and estimates often vary depending on data and definitions used. For the U.S. the National Institute of Health (NIH) estimated the costs of all cancer care entities at US\$226.8 billion, divided into direct medical costs (total of all health expenditures) of US $\$ 103.8$ billion and US $\$ 123.0$ billion just for indirect mortality costs (cost of lost productivity due to premature death) [10]. Breast cancer is the third most costly type of cancer worldwide with an estimated global impact of $€ 88$ billion per year [11]. Just recently the costs of all cancer entities have been calculated at $€ 124$ billion per year for Europe with costs for breast cancer alone calculated at about $€ 6$ billion per year [12]. However indirect costs for breast cancer exceed the direct costs further, and are estimated to be at least 3 times higher $[13,14]$ and only minimally include peripheral indirect costs like those incurred by cancer caregivers [15]. For Germany the direct costs of breast cancer for 2002 were calculated at $€ 1,564$ billion, and indirect costs were listed as not available [16]. However for 2002 in Germany the lost years of life were calculated at 386,000 life years, and in addition 65,000 years of work life were lost because of breast cancer [17]. The direct cost for treating breast cancer increased over the next 6 years from 2002 to 2008 to $€ 1,970$ billion $(+26.0 \%)$ [18], an increase far above a compensation of the inflation rate. Interestingly a recent study pointed out that Germany has currently the highest costs of cancer per capita in Europe with $€ 126$ per year and also with over $€ 28,000$ per incident of cancer [12], which begs the question as to why these costs seem not to be reflected in a proportionally improved outcome compared to other European countries. The costs of oncological pharmaceuticals have been remarkably increasing over the last decades, and therefore the limitation of further increases of oncological medication costs is subject of a controversial debate [19]. Excessive costs and economic interests might even make patients feel used and reduced to an economic target, turning them against any reasonable therapy advice [20]. Finally breast cancer patients tend to also live in middle- and low-income countries around the world with often very limited resources, so the demand for economically affordable breast cancer care [21] and guidelines addressing this aspect [22,23] are important issues. 
Examples of Successful Microeconomic Management Projects in Breast Cancer Treatment

Successful microeconomic projects in breast centers require active management and the integration of management at the clinic level [24, 25]. Clinical resource steering requires timely access to all relevant cost and reimbursement information. Besides monthly cost and key data reporting, price lists of internal and external medical services and pharmaceutical and disposable costs must be taken into account. Based on and derived from this information, cost drivers can preferably be identified, and a cautious and gentile long-term optimization process can be induced towards a care-to-reimbursement adjustment. Over the years a variety of successful projects have evolved among them; optimizing chemotherapy reimbursement with reduction of oncological pharmaceutical costs by over $83 \%$ in just 2 years without changing quality of care [2628], comparison of different chemoregimen [29], process analysis to discover mistakes in ordering, cost attribution, documentation, coding and billing for out-patient chemotherapies [30], prospective analysis of cost and reimbursement for participation in clinical trials [31], identification of off-label status for pharmaceuticals which are not reimbursed by statutory healthcare funds [32], analysis of costs and financial risks of expensive breast implants at $90 \%$ under-reimbursed in immediate breast reconstruction after mastectomy [33], prospective study of provider's costs of chemotherapy-related complications such as febrile neutropenia [34] and analysis and optimization of their correlating DRG reimbursement [35], prospective calculation of direct medication cost savings by biomarkers for avoiding chemotherapy in breast cancer at medium relapse risk [36], purchase and contract adjustments for reduction of costs of expensive breast ultrasound equipment to actual clinical needs [37], and identifying unexplainable reimbursement differences of mastectomy between prophylactic BRCA1/BRCA2 and breast cancer patients [38]. Even concordance of biomarker test results to Tumor Board decisions and final therapy can result in economic effects which can be used to optimize cost for their application [39].

Another successful approach to limiting costs is through major medical societies like ASCO encouraging the elimination of staging in small breast cancers, expensive imaging in follow-up of asymptomatic breast cancer in the adjuvant setting or rational use of granulocyte colony-stimulating factor (G-CSF) for febrile neutropenia prophylaxis during chemotherapy [40]. Recently the Choosing Wisely campaign was set up to encourage physicians to move from excessive medical service expansion back to reasonable patient care. The world's largest oncological society (ASCO) supports this project and has identified 5 key issues to improve care and save costs at the same time [41]. Among these, 4 statements focus and address how breast cancer treatment can increase quality of life for patients by doing less instead of the usual more diagnostics and therapy:
\#1: 'Don't use cancer-directed therapy for solid tumor patients with the following characteristics: low performance status (3 or 4 ), no benefit from prior evidence-based interventions, not eligible for a clinical trial, and no strong evidence supporting the clinical value of further anti-cancer treatment.'

\#3: 'Don't perform PET, CT and radionuclide bone scans in the staging of early breast cancer at low risk for metastasis.'

\#4: 'Don't perform surveillance testing (biomarkers) or imaging (PET, CT and radionuclide bone scans) for asymptomatic individuals who have been treated for breast cancer with curative intent.'

\#5: 'Don't use white cell stimulating factors for primary prevention of febrile neutropenia for patients with less than $20 \%$ risk for this complication.'

Besides the ethical benefit in patient care, economically the acceptance and unrestricted implementation of these guidelines could serve as an example how to improve quality of care and save resources at the same time.

\section{Economic Management Perspectives}

Economic aspects and changes can be identified for all stakeholders in healthcare and might lead to changes in the perspective and consecutive adjustment to new tasks and developments.

\section{Economic Management Perspective for Hospitals and Breast Centers}

In fixed healthcare reimbursement systems like the German DRG system, the amount of resources available to treat breast cancer is limited for each case. So over the last decade economic aspects have become an integral and non-negligible part of the treatment process and are repeatedly addressed by the German Society for Gynecology and Obstetrics (DGGG) $[2,42]$. As a consequence hospitals and breast centers have to analyze costs and reimbursements and adjust them accordingly to avoid potential losses which are not covered. Losses can occur from providing high-quality care in certified breast centers as calculated [43, 44], from the use of expensive devices like breast implants which are not covered at $90.3 \%$ for immediate breast reconstruction after mastectomy [33], or from insufficient processes of chemotherapy reimbursement if not controlled [30]. At the present time the question is unsolved of how quality of care can be paid for [45, 46]. Costly structural quality as provided by most certified breast centers at their own expense, university level of care or long-term outcomes are not integrated into German DRG reimbursement at this point. Other sources of financing are being evaluated [47]. These economic aspects have become so important for hospitals that the incorporation of management experience within the physicians' team to steer costs and resources 
at the clinic level is necessary. This has already proven to be cost-effective, e.g. understanding of costs for chemo-related febrile neutropenia prophylaxis medication vs. their reimbursement [48], reducing in-patient costs for chemotherapy by $€ 900,000$ per year [28], and has even lead to a new profession $[24,25]$.

\section{Economic Management Perspective for Physicians in Breast Centers and Hospitals}

Under the current DRG system physicians are held responsible for cost-covering care. There is no alternative to taking on this responsibility, since it is the physicians who are the only profession able to prioritize resources and their value for care, and weighting and balancing quality of care with costs and their reimbursement to achieve the best care available with predefined resources. Optimized process management includes transparency and steering according to prizes, costs, and reimbursement. Adequate adjustment needs to be implemented and constantly verified. To qualify for this task further education in basic hospital economics to regain process control and professional freedom is necessary.

\section{Economic Management Perspective}

of Hospital Administration

Hospital administrations have to reevaluate their actual influence on hospital economics and readjust to the obvious changes towards a more direct clinic-based resource steering. This might be supported by the implementation of a profitcenter principle with the consecutive transfer of economic responsibility to physicians. Among the tasks are providing cost transparency with pricelists and cost-reimbursement information to physicians, developing economic tools for physicians' clinical application, increasing the transfer of information from the administrative to the clinical level, and developing horizontal communication within the hospital's different sections. To be successful they have to increase freedom and responsibility for physicians in charge of clinical economics at the same time and substitute traditional clinic-external controllers with clinic-internal economic management at the point of care and resource decision making. Increasing competitiveness is reached by converting fixed department budgets of all service providers towards actual supply and demand by their customers - the clinics. The development of financial incentives for resource steering and cost-covering care can accelerate this process. Overall hospital administrations have to create an integrated concept of economic, administrative, financial, and medical care for breast centers.

\section{Economic Management Perspective of Medical}

\section{Specialty Societies}

Medical specialties have to tackle the need for integrating economics into clinical practice by addressing the topic and implementing hospital economics into further medical education and professional meetings. They might encourage physi- cians to take responsibility for hospital economics and thereby improve the degree of professional freedom. Medical specialty societies have the power to be used for political influence on the ongoing economization process and might be able to address and suggest solutions for areas of inadequate funding.

Economic Management Perspective of Payers, Health Funds, and Medical Services of Health Funds (MDKs)

MDKs (Medizinischer Dienst der Krankenversicherung) have expanded from the German social security code (Sozialgesetzbuch, SGB) SGB V $\$ 275$ the right to verify any medical in-patient treatment and hospital invoice [49]. However this tool to create equal power between care providers and insurance payers has been extremely overstretched within the last years. Predefined absurd targets of challenging and objecting $12.5 \%$ or more of all hospital invoices by MDKs leading often not to a reduction of reinbursement of hospital invoices but results in an excessive and costly administrative waste of resources among physicians and their hospital administration which has increased tensions between both groups over time. From the economic perspective it might be more useful to abandon the destructive administrative pathway and decide on a more active and peace-keeping approach. All payers, healthcare funds, insurances, and also MDKs should be encouraged to support economic clinic management by identifying better quality of care with innovative diagnostics and therapies which result in savings or a more reasonable use of resources for the society. This innovation support could help to promote and encourage the implementation of new techniques. Also clinical studies and evidence-based trials designed by healthcare funds or insurances might be an option to better understand quality of care issues and proactively identify and support better diagnostics and therapies.

\section{Economic Management Perspective of Quality Certification for Germany and Europe (EUSOMA)}

Breast cancer certification institutions like OnkoZert for Germany and EUSOMA for Europe have to accept that quality of care cannot be provided independent of the resources available. Therefore the certification process will have to integrate best quality patient care which is defined on a supranational level within country-specific health economic rules and resource limitations. Analog to different degrees of prioritization of treatment care the quality of care has to be adjusted accordingly. Furthermore certification institutions have to identify the indirect costs of the certification process for their certification partner and support prioritizing and balancing cost-adjusted quality measures.

\section{Economic Management Perspective for Patients}

Patients have often personally felt the economic changes in the DRG healthcare system over the last decade. Patients should understand that the limitation of resources for healthcare is done by elected politicians and not by their caring 
physicians. All citizens as future potential patients should get involved and carefully evaluate changes and healthcare reforms for their own economic interests and act against changes that are not in their overall interest. Over time patients are likely to expect to pay more out of their own pockets for reasonable additional or even essential care rather than this being paid for by the healthcare system.

\section{Economic Management Perspective of Healthcare Politicians} Politicians have to integrate different stakeholders' perspectives on healthcare. They must continue implementing economic rules to steer cost-conscious diagnostics and therapies. To take advantage of proven cost-effectiveness they should integrate and assure that long-term savings for other stakeholders are transferred to those who invest in cost-effective measures. They also have to address the elimination of potential moral hazards for physicians in the ethical conflict of costs vs. care and any direct and indirect benefit of unreasonable medical service expansion for the treating physician including excessive use of diagnostics and therapy with unproven or no benefit for the patient, e.g. use of expensive oncological pharmaceuticals for breast cancer [50]. Politicians also have to identify the true costs of quality structures, e.g. by additional InEK calculations for certified breast centers, and implement cost-covered funding if permanent certification of breast centers is appreciated.

\section{Selected Topics with Economic Impact}

\section{Future of Certified Breast Centers}

The certification 'wave' of breast centers being certified by OnkoZert [51] according to Deutsche Krebsgesellschaft (DKG) and Deutsche Gesellschaft für Senologie (DGS) criteria for Germany or EUSOMA [52] for Europe over the last decade has presently resulted in over 200 certified breast centers [53]. This has remarkably standardized the structural quality of breast centers, thereby improving quality of care as well as homogenizing treatment standards in breast cancer treatment in Germany. Disappointingly certified and non-certified breast centers are identically reimbursed according to the DRG, without adequate payment for additional structural quality costs. However certified breast centers and certification institutions will have to take into account country-specific financial limitations of any healthcare system and adjust quality requirements accordingly because provision of unlimited quality structures, e.g. with breast nurses, psycho-oncological support or documentation of life-long follow-ups, is extremely costly and economically not compensated for in any way in the current DRG system. Although the DRG-issuing institution InEK has comprehensive access to all financial data of German hospitals to identify the additional structure quality costs for certified breast centers, they have rejected an at- tempt by the DRG Commission at the German Physicians' Chamber (BAEK) in Berlin to analyze and identify the actual quality structure costs since they claim that it is not their politically assigned task [54]. In the long run it will finally be up to the government to decide if certified breast centers are financially adequately compensated and if they can continue their work at the present level which is highly appreciated by breast cancer patients. The alternative of certified breast centers underfunded due to missing resources or potentially moving breast care treatment from an in-patient to an outpatient setting will eliminate the currently certified in-patient breast center treatment concept. An adjustment of DRGs to cover this financial gap is strongly suggested. This was also supported by a recent comparison of breast cancer DRGs in 10 European countries showing that flat-rate reimbursement can vary between different countries as well as payment over time, concluding that policy makers in 7 countries should re-evaluate their DRG systems regarding algorithms and classification for appropriateness [55]. Repeated analyses of DRGs in breast cancer treatment by clinical physicians have shown that despite a 10-year learning process German DRGs are still not cost-covering for the breast cancer care provided $[33,56,57]$.

\section{Evaluation of the Actual Benefit of New Therapies}

New diagnostics and therapies in breast cancer treatment are often enthusiastically promoted at market access. The costs for oncological pharmaceuticals have risen remarkably but in contrast offer often a rather small benefit for overall survival or are even withdrawn after not showing the desired ratio of risks vs. benefits. But if the margin of benefit is rather small or zero and end targets of clinical studies might not show distinct benefits, a one-size-fits-all approach of standard chemotherapy for a statistical benefit of just a few who remain unidentified in advance may be substituted with a more personalized approach. Weighting costs and real benefits together with comprehensively informed and actively decision-making patients might lead to a more rational, individual, and also cost-saving approach [58].

\section{Compliance of Breast Cancer Therapy by Patients}

Due to varying biological factors and individual course of disease physicians cannot guarantee individual outcome of a treatment since outcome results are merely statistical results for large groups of the same entity. Additionally patient compliance can limit diagnostic and therapy effects in breast cancer as seen in the still limited use of screening mammography or a decreased long-term compliance in anti-hormonal medication with tamoxifen and/or aromatase inhibitors over the recommended 5 years. Physicians can only be held responsible if they can fully control the outcome. This results in economic effects which should be analyzed and taken into account. 
End-of-Life Medical Costs

End-of-life medical costs are increasing for cancer suffers as well as other patients. Patients have the undeniable right of access to palliative and supportive care in the last stages of oncological disease. Treatment with chemotherapy until death has no rationale, reduces quality of life even further than necessary, consumes resources without benefits to the patient, and is in the end unethical. Although challenging, it might be reasonable to identify and accept the last stage of the disease and improve the quality of the remaining life of prefinal patients by not extending aggressive oncological therapy until the last day of their life. A simple measure of reducing reimbursement for chemotherapy by $50 \%$ in prefinal patients within the last 2 weeks before death was able to decrease by $20 \%$ the likelihood of chemo-application within this time period [59].

\section{Conclusion}

Breast cancer has remarkable economic relevance. The costs and resources used can lead to losses for breast centers if not controlled and adjusted accordingly in relation to their reimbursements. New diagnostics and therapies for breast cancer will not only have to show their individual cost-effectiveness but moreover how they fit into the reimbursement system. All stakeholders have to increase cost transparency and communication for the better management of available resources. Active microeconomic management of clinical resources at the clinic level in breast centers has proven to be highly successful in varying projects. Finally, physicians are the only professional group who can balance patient care and cost-toreimbursement, and in doing so should also be supported with the necessary information and resources from all stakeholders.

\section{Disclosure Statement}

The authors have no conflict of interest to declare.

\section{References}

1 Lux MP, Reichelt C, Karnon J, Tänzer TD, Radosavac D, Fasching PA, Beckmann MW, Thiel FC: Cost-benefit analysis of endocrine therapy in the adjuvant setting for postmenopausal patients with hormone receptor-positive breast cancer, based on survival data and future prices for generic drugs in the context of the German health care system. Breast Care 2011;6:381-389.

2 Beckmann MW, Bader W, Bechtold I, Becker S, Bornhaupt J, Dimpfl T, Friese K, Frobenius W, U. Gembruch U, Grüßner S, Heer IM, Kayser D, Kreienberg R, Petri E, Rimbach S, Scharl A, Schmidt S, Schwenzer T, Solomayer E, et al.: Finanzierung und finanzielle Probleme von Leistungen und Strukturen im Fachgebiet Gynäkologie und Geburtshilfe im Jahr 2011 - allgemeine Aspekte und geburtshilfliche Versorgung. Geburtsh Frauenheilk 2011;71:367-380.

3 Institut für das Entgeltsystem im Krankenhaus (InEK): DRG Report Browser 2012. www.g-drg.de/ cms/G-DRG-System_2012/Abschlussbericht_zur_ Weiterentwicklung_des_G-DRG-Systems_und_ Report_Browser/Report-Browser_2010_2012; accessed 14 Dec 2012

4 Brown ML, Lipscomb J, Snyder C: The burden of illness of cancer: economic cost and quality of life. Annu Rev Public Health 2001;22:91-113.

5 Barron JJ, Quimbo R, Nikam PT, Amonkar MM: Assessing the economic burden of breast cancer in a US managed care population. Breast Cancer Res Treat 2008;109:367-377.

6 Campbell JD, Ramsey SD: The costs of treating breast cancer in the US: a synthesis of published evidence. Pharmacoeconomics 2009;27:199-209.

7 Allen JM: Economic/societal burden of metastatic breast cancer: a US perspective. Am J Manag Care 2010;16:697-704.
8 Vera-Llonch M, Weycker D, Glass A, Gao S, Borker R, Qin A, Oster G: Healthcare costs in women with metastatic breast cancer receiving chemotherapy as their principal treatment modality. BMC Cancer 2011:11:250

9 Canadian Breast Cancer Network (CBCN): Breast cancer: economic impact and labour force re-entry. Ottawa, Canada 2010. www.cbcn.ca/documents/ Labour_Force_Re-Entry_Report_ENG_CBCN 2010.pdf; accessed 13 Dec 2012.

10 American Cancer Society (ACS): Cancer Facts and Figures 2012. Atlanta, GA, American Cancer Society, 2012. www.cancer.org/acs/groups/content/ @epidemiologysurveilance/documents/document/ acspc-031941.pdf; accessed 13 Dec 2012.

11 American Cancer Society (ACS): The Global Economic Cost of Cancer. Atlanta, GA, American Cancer Society, 2010. www.cancer.org/acs/groups/ content/@internationalaffairs/documents/document/ acspc-026203.pdf; accessed 13 Dec 2012.

12 Luengo-Fernandez R, Leal J, Sullivan R: Economic burden of malignant neoplasms in the European Union. Ann Oncol 2012;23(suppl 9):ixe25.

13 Chirikos TN: Cancer economics: economic impact of the growing population of breast cancer survivors. Cancer Control 2001;8:177-183.

14 Scitovsky AA, McCall N: Economic impact of breast cancer. Front Radiat Ther Oncol 1978;11:90-101.

15 Mori A, Goren A, Gilloteau I, Dibonaventura MD: Quantifying the burden of caregiving for patients with cancer in Europe. Ann Oncol 2012;23 (suppl 9):ixe25-6.

16 Giersiepen K, Heitmann C, Janhsen K, Lange C: Brustkrebs. Gesundheitsberichterstattung des Bundes (GBE), Heft 25. Berlin, Robert Koch-Institut, Mai 2005. www.rki.de/DE/Content/Gesundheitsmonitoring/ Gesundheitsberichterstattung/Themenhefte/brustkrebs_ inhalt.html?nn=2543868; accessed 13 Dec 2012.
17 Statistisches Bundesamt: Gesundheit. Krankheitskosten 2002. Wiesbaden, 2004.

18 Gesundheitsberichterstattung des Bundes: Krankheitskosten von Brustkrebs für Deutschland. www.gbe-bund.de; accessed 13 Dec 2012.

19 Bach PB: Limits on Medicare's ability to control rising spending on cancer drugs. $\mathrm{N}$ Engl $\mathrm{J}$ Med 2009;360:626-633.

20 Fischl F, Feiertag A: Wirtschaftsfaktor Brustkrebs - Werden Frauen und ihre Ängste instrumentalisiert? Wien/NewYork, Springer, 2005; ISBN 3-211-23594-9.

21 Elzawawy A: Breast cancer systemic therapy: the need for more economically sustainable scientific strategies in the world. Breast Care (Basel) 2008;3:434-438.

22 Anderson BO, Yip CH, Smith RA, Shyyan R, Sener SF, Eniu A, Carlson RW, Azavedo E, Harford J: Guideline implementation for breast healthcare in low-income and middle-income countries: overview of the Breast Health Global Initiative Global Summit 2007. Cancer 2008;113 (8 suppl):2221-2243.

23 El Saghir NS, Eniu A, Carlson RW, Aziz Z, Vorobiof D, Hortobagyi GN; Breast Health Global Initiative Systemic Therapy Focus Group: Locally advanced breast cancer: treatment guideline implementation with particular attention to low- and middle-income countries. Cancer 2008;113 (8 suppl):2315-2324.

24 Jacobs VR, Mallmann P: Chief medical clinic manager of a university OB/GYN clinic - an innovative job description as management response for increase of profitability, quality of care, and physicians' freedom of action. Onkologie 2010; 33:331-336.

25 Jacobs VR: Aufgaben und Funktion eines Abrechnungsexperten in einer Frauenklinik. Gynäkologe 2010;43:393-399. 
26 Jacobs VR, Thoedtmann J, Brunner B, Kiechle M: An economic model to reduce the cost of chemotherapy for gynecologic cancer. Int J Fertil Womens Med 2004;49:274-277.

27 Jacobs VR, Thödtmann J, Brunner B, Kiechle M: Modell eines aktiven Kostenmanagements gynäkoonkologischer Therapien zur Reduktion der Medikamentenkosten um 58.7\% innerhalb eines Jahres. Geburtshilfe Frauenheilkd 2005:65:46-55.

28 Jacobs VR, Thoedtmann J, Euler U, Paepke S, Fischer T, Harbeck N, Kiechle M: Physician-based active cost management of oncological therapies reducing pharmaceutical costs by $83.4 \%$ in two years without leaving standard of care. Onkologie 2005;28:441-445.

-29 Braun M, Jacobs VR, Wagenpfeil S, Sattler D, Harbeck N, Nitz U, Bernard R, Kuhn W, Ihbe-Heffinger A: Cost analysis comparing an anthracycline/docetaxel regimen to $\mathrm{CMF}$ in patients with early stage breast cancer. Onkologie 2009;32:473-481.

30 Jacobs VR, Mallmann P: Financial quality control of in-patient chemotherapy in Germany: are additional payments cost-covering for pharmaco-oncological expenses? Breast Care (Basel) 2011;6:120125.

31 Jacobs VR: Making or losing money with participation in clinical trials: a decision analysis. Onkologie 2009;32:411-416.

32 Jacobs VR: Current status of financing and reimbursement of herceptin (Trastuzumab) for adjuvant and advanced therapy of breast cancer in Germany. Breast Care 2006;1:86-94.

-33 Jacobs VR, Rasche L, Harbeck N, Warm M, Mallmann P: Underfinancing of $90.3 \%$ for implant costs of prostheses and expanders in DRGrevenues for uni- and bilateral mastectomy with immediate breast reconstruction. Onkologie 2010; 33:584-588.

-34 Ihbe-Heffinger A, Paessens BJ, von Schilling C, Shlaen M, Gottschalk N, Berger K, Bernard R, Kiechle M, Peschel C, Jacobs VR: Management of febrile neutropenia - a German prospective hospital cost analysis in lymphoproliferativ disorders, non-small cell lung cancer, and primary breast cancer. Onkologie 2011;34:241-246.

\35 Jacobs VR, Mayer SC, Paessens BJ, Bernard R, Harbeck N, Kiechle M, Ihbe-Heffinger A: Comparison of hospital costs vs. DRG revenues for in-patient treatment of febrile neutropenia during adjuvant anthracycline \pm taxane-based CTX for primary breast cancer. Onkologie 2011;34:614-618.

36 Jacobs VR, Augustin D, Wischnik A, Kiechle M, Hoess C, Steinkohl O, Rack B, Kapitza T, Krase P: CTX and CTX-related direct medication costs saved by testing biomarkers uPA and PAI-1 in primary breast cancer: results of a prospective multi-center study at Certified Breast Centers in Germany. Cancer Res 2012;72(24 suppl):S457.
37 Jacobs VR, Mallmann P: Finanzielle Qualitätssicherung durch Ressourcenmanagement 'von innen' durch Ärzte: Sechs ökonomisch erfolgreiche Projekte an der Uniklinik Köln und ihr Einsparungspotential. Arch Gynecol Obstet 2012; 286(suppl 1):S138.

38 Rasche L, Jacobs VR: Prophylactic bilateral mastectomy in BRCA-1 and BRCA-2: unreasonable difference of $1,534.22 €$ in reimbursement for similar operations with same costs and effort. Arch Gynecol Obstet 2010;282(suppl):S234-235.

39 Jacobs VR, Augustin D, Wischnik A, Kiechle M, Hoess C, Steinkohl O, Rack B, Kapitza T, Krase P: Analysis of test-therapy concordance for biomarkers UPA and PAI-1 in primary breast cancer in clinical hospital routine: results of a prospective multi-center study at Certified Breast Cancers in Germany. Cancer Res 2012;72(24 suppl):S455-456.

40 Choosing Wisely. www.abimfoundation.org/ Initiatives/Choosing-Wisely.aspx; accessed on 12 Dec 2012.

41 Schnipper LE, Smith TJ, Raghavan D, Blayney DW, Ganz PA, Mulvey TM, Wollins DS: American Society of Clinical Oncology identifies five key opportunities to improve care and reduce costs: the top five list for oncology. J Clin Oncol 2012;30: 1715-1724.

42 Beckmann, MW, Bader W, Bechtold I, Becker S, Bornhaupt J, Dimpfl T, Friese K, Frobenius W, Gembruch U, Grüßner S, Heer IM, Kayser D, Kreienberg R, Petri E, Rimbach S, Scharl A, Schmidt S, Schwenzer T, Solomayer E, Steiner E, Strauss A, Vetter K, Wallwiener D, Lux MP: Finanzierung und finanzielle Probleme von Leistungen und Strukturen im Fachgebiet Gynäkologie und Geburtshilfe im Jahr 2011 - DRG-System und stationäre Versorgung inklusive Urogynäkologie und benigner wie auch maligner gynäkologischer Operationen. Geburtsh Frauenheilk 2011;71:497510.

43 Beckmann WM, Kaufmann M: Ist die Versorgung von Patientinnen mit Mammakarzinom im derzeitigen Vergütungssystem finanzierbar - Wird Qualität auch bezahlt in Brustzentren? Geburtsh Frauenheilk 2007;67:957-958.

44 Beckmann MW, Bani MR, Loehberg CR, Hildebrandt T, Schrauder MG, Wagner S, Fasching PA, Lux MP: Are certified breast centers costeffective? Breast Care (Basel) 2009;4:245-250.

45 Beckmann MW, Bechtold I, Debus G, Feige A, Frobenius W, Kiesel L, Kunzmann U, Lux M, Sehouli J, Solomayer E, Steiner E, Wagner S: Ist die zukünftige Finanzierung von medizinischer Qualität noch gesichert? Bericht der Finanzierungskommission der DGGG e.V. - Teil I. Geburtsh Frauenheilk 2008;68:1204-1214.

46 Beckmann MW, Bechtold I, Debus G, Feige A, Frobenius W, Kiesel L, Kunzmann U, Lux MP, Sehouli J, Solomayer E, Steiner E, Wagner S,
Schwenzer T, Kreienberg R, Wallwiener D: Ist die zukünftige Finanzierung von medizinischer Qualität noch gesichert? Bericht der Finanzierungskommission der DGGG e.V. - Teil II. Geburtsh Frauenheilk 2009;69:56-65.

47 Thiel FC, Scharl A, Hildebrandt T, Kotziabassis E, Schrauder MG, Bani MR, Müller A, Hauzenberger T, Loehberg CR, Jud SM, Fasching PA, Hartmann A, Schulz-Wendtland R, Strnad V, Beckmann MW, Lux MP: Financing of certified centers: a willingness-to-pay analysis. Arch Gynecol Obstet 2012; Epub ahead of print.

48 Jacobs VR, Mayer SC, Paessens BJ, Bernard R, Harbeck N, Kiechle M, Ihbe-Heffinger A: Comparison of actual hospital costs versus DRG revenues for in-patient treatment of febrile neutropenia during adjuvant anthracycline plus/minus taxanebased chemotherapy for primary breast cancer. Onkologie 2011;34:614-618.

49 Sozialgesetzbuch SGB V. www.gesetze-im-internet. de/sgb_5/_275.html; accessed on 17 Dec 2012.

50 Böhmann D: Bonuszahlungen für Fallzahlen? Wider die ökonomischen Determinanten ärztlichen Handelns; in Forschung und Lehre 2012, pp. 992-993. www. forschung-und-lehre.de.

51 OnkoZert. www.onkozert.de/brustkrebszentren.htm; accessed on 12 Dec 2012

52 European Society of Breast Cancer Specialists (EUSOMA). www.eusoma.org; accessed on $12 \mathrm{Dec}$ 2012.

53 OnkoZert. www.onkozert.de/brustkrebszentren/ karte.htm; accessed on 12 Dec 2012.

54 Institut für das Entgeltsystem im Krankenhaus (InEK): Anfrage zur differenzierten Auswertung der InEK-Kalkulationsdaten nach Strukturqualität. Reply letter to DRG Commission at Bundesärztekammer Berlin (BAEK) from 21.01.2010.

55 Scheller-Kreinsen D, Euro DRG Group: How well do diagnosis-related group systems group breast cancer surgery patients? Evidence from 10 European countries. Health Econ 2012;21(suppl 2):41-54.

56 Hoffmann J, Wallwiener D: Breast cancer surgery and financial reimbursement in Germany. Breast Care 2012;7:384-388.

\$57 Lotter O, Amr A, Jaminet P, Hoefert S, Schaller HE, Stahl S: (Development of DRGs in reconstructive breast surgery). Handchir Mikrochir Plast Chir. 2012;44:112-117.

58 Kuhrt N: Was darf ein Monat Leben kosten? Frankfurter Allgemeine Zeitung (FAZ) 20.01.2010. www.faz.net/aktuell/wissen/medizin/krebstherapiewas-darf-ein-monat-leben-kosten-1907448.html; accessed on 12 Dec 2012

59 Colla CH, Morden NE, Skinner JS, Hoverman JR, Meara E: Impact of payment reform on chemotherapy at the end of life. Am J Manag Care 2012; 18:e200-8. 